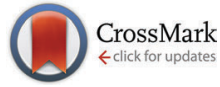

Cite this: Phys. Chem. Chem. Phys., 2015, 17, 2259

Received 9th October 2014 Accepted 27th November 2014

DOI: $10.1039 / c 4 c p 04574 b$

www.rsc.org/pccp

\title{
Using beryllium bonds to change halogen bonds from traditional to chlorine-shared to ion-pair bondst
}

\author{
Ibon Alkorta, ${ }^{a}$ José Elguero, ${ }^{* a}$ Otilia Mó, *b Manuel Yáñez*b and \\ Janet E. Del Bene*c
}

\begin{abstract}
Ab initio MP2/aug'-cc-pVTZ calculations have been carried out to investigate the structures, binding energies, and bonding characteristics of binary complexes $\mathrm{HFBe}: \mathrm{FCl}, \mathrm{R}_{2} \mathrm{Be}: \mathrm{FCl}$, and $\mathrm{FCl}: \mathrm{N}$-base, and of ternary complexes HFBe:FCl:N-base and $\mathrm{R}_{2} \mathrm{Be}: \mathrm{FCl}$ : $\mathrm{N}$-base for $\mathrm{R}=\mathrm{H}, \mathrm{F}, \mathrm{Cl} ; \mathrm{N}$-base $=\mathrm{NH}_{3}, \mathrm{NHCH}_{2}, \mathrm{NCH}$. Dramatic synergistic cooperative effects have been found between the Be...F beryllium bonds and the $\mathrm{Cl} \ldots \mathrm{N}$ halogen bonds in ternary complexes. The $\mathrm{Cl} \ldots \mathrm{N}$ traditional halogen bonds and the Be...F beryllium bonds in binary complexes become significantly stronger in ternary complexes, while the $\mathrm{F}-\mathrm{Cl}$ bond weakens. Charge-transfer from $\mathrm{F}$ to the empty $\mathrm{p}(\sigma)$ orbital of Be leads to a bending of the XYBe molecule and a change in the hybridization of $\mathrm{Be}$, which in the limit becomes $\mathrm{sp}^{2}$. As a function of the intrinsic basicity of the nitrogen base and the intrinsic acidity of the Be derivative, the halogen-bond type evolves from traditional to chlorine-shared to ion-pair bonds. The mechanism by which an ion-pair complex is formed is similar to that involved in the dissociative proton attachment process. EOM-CCSD spin-spin coupling constants ${ }^{1 \mathrm{X}} \mathrm{J}(\mathrm{Cl}-\mathrm{N})$ across the halogen bond in these complexes also provide evidence of the same evolution of the halogen-bond type.
\end{abstract}

\section{Introduction}

Noncovalent interactions play a fundamental role in supramolecular chemistry, molecular biology, and materials science. The earliest research in this field focused on the most common noncovalent interaction, the hydrogen bond. However, in the past few decades, interest has increased in other intermolecular interactions, including the halogen bond, the pnicogen bond, and the beryllium bond.

The halogen bond arises when a halogen atom ( $\mathrm{F}, \mathrm{Cl}, \mathrm{Br}$ or I) acts as the acid in a Lewis acid-Lewis base interaction. The molecules involved in the formation of halogen bonds usually have molecular electrostatic potentials (MEPs) at the interacting

\footnotetext{
${ }^{a}$ Instituto de Quimica Médica (IQM-CSIC), Juan de la Cierva 3, 28006-Madrid, Spain.E-mail: ibon@iqm.csic.es, iqmbe17@iqm.csic.es

${ }^{b}$ Departamento de Química, Módulo 13, Universidad Autónoma de Madrid, Campus de Excelencia UAM-CSIC, Cantoblanco, 28049 Madrid, Spain. E-mail: otilia.mo@uam.es, manuel.yanez@uam.es

${ }^{c}$ Department of Chemistry, Youngstown State University, Youngstown, Ohio 44555, USA.E-mail: jedelbene@ysu.edu

$\dagger$ Electronic supplementary information (ESI) available: MEP minima and maxima on monomer surfaces; total energies, structures, and molecular graphs of binary and ternary complexes; electron density properties at BCPs; NBO bond orders; MBIE energies; PSO, DSO, FC, and SD components of coupling constants. See DOI: 10.1039/c4cp04574b
}

halogen atoms that exhibit positive regions, known as $\sigma$-holes. ${ }^{1-3}$ Recently, both traditional and chlorine-shared halogen bonds have been described in complexes $(\mathrm{Ph})_{3} \mathrm{P}: \mathrm{Cl}_{2}, \mathrm{YCl}: \mathrm{CNX}$, YCl:SiNX, $\mathrm{H}_{2} \mathrm{FP}$ :ClY, and $\mathrm{H}_{2} \mathrm{XP}$ :ClY, with $\mathrm{Y}=\mathrm{F}, \mathrm{Cl}$, and $\mathrm{X}$ a variety of substituents, ${ }^{4-11}$ as well as in complexes of nitrogen-heterocyclic carbenes with halogen bond donors. ${ }^{12}$

In contrast, only a few studies of intermolecular beryllium bonds have appeared in the literature. Studies of beryllium bonds in complexes between $\mathrm{BeH}_{2}$ and $\mathrm{HArF}^{13}$ have been reported, and the results analyzed using the QTAIM methodology. ${ }^{14}$ Previously, we investigated the beryllium bonds formed between the acids $\mathrm{BeX}_{2}$, for $\mathrm{X}=\mathrm{H}, \mathrm{F}, \mathrm{Cl}$, and $\mathrm{OH}$, and a variety of Lewis bases. ${ }^{15}$ These bonds have bond critical points, and in some cases slightly negative energy densities, indicating partial covalent character. In addition, bonding indices also suggest that intermolecular bonds involving beryllium share some common features with hydrogen bonds. ${ }^{15}$ We have also investigated cooperativity in beryllium-bonded clusters of the (iminomethyl)beryllium hydride and (iminomethyl)beryllium fluoride, and concluded that there is a positive cooperativity, or synergy, as found for hydrogen-bonded chains. ${ }^{16}$ In addition, the acidity of the $\mathrm{N}-\mathrm{H}$ group of an imidazole hydrogen-bonded dimer is greatly enhanced by complexation with $\mathrm{BeX}_{2}$, for $\mathrm{X}=\mathrm{H}, \mathrm{F}$, giving evidence of cooperativity between hydrogen bonds and beryllium bonds. ${ }^{17}$ Cooperativity between beryllium bonds and other noncovalent interactions has also been reported. ${ }^{18,19}$ 
Our previous study of uncharged binary complexes of FCl with a variety of $\mathrm{sp}, \mathrm{sp}^{2}$, and $\mathrm{sp}^{3}$ hybridized nitrogen bases indicated that only complexes with traditional $\mathrm{F}-\mathrm{Cl} \cdots \mathrm{N}$ halogen bonds are formed. ${ }^{20}$ In the present study, we ask the question of whether or not the presence of a strong acid such as $\mathrm{BeH}_{2}$ and its derivatives bonded to $\mathrm{FCl}$ can alter the type of $\mathrm{F}-\mathrm{Cl} \cdots \mathrm{N}$ halogen bond formed with a neutral nitrogen base. The complexes included in this study are the binary complexes HFBe:FCl, $\mathrm{R}_{2} \mathrm{Be}: \mathrm{FCl}$, and FCl:N-base, and the ternary complexes represented as HFBe:FCl:N-base and $\mathrm{R}_{2}$ Be:FCl:N-base, with $\mathrm{R}=\mathrm{H}, \mathrm{F}$ and $\mathrm{Cl}$; and $\mathrm{N}$-base the $\mathrm{sp}, \mathrm{sp}^{2}$, and $\mathrm{sp}^{3}$ hybridized bases $\mathrm{NCH}, \mathrm{NHCH}_{2}$, and $\mathrm{NH}_{3}$, respectively. We have computed the structures, binding energies, various bonding properties, and spin-spin coupling constants for binary and ternary complexes, which are stabilized by beryllium bonds and halogen bonds. The results of these calculations and their interpretation are reported in this paper.

\section{Methods}

The structures of the isolated monomers and binary and ternary complexes were optimized at second-order MøllerPlesset perturbation theory (MP2) ${ }^{21-24}$ with the aug'-cc-pVTZ basis set. ${ }^{25}$ This basis set is derived from the Dunning aug-ccpVTZ basis set ${ }^{26,27}$ by removing diffuse functions from $\mathrm{H}$ atoms. In addition, the structures of the ions (XYBeF) ${ }^{-}$and ${ }^{+}$(Cl-N-base) have also been determined. Frequencies were computed to establish that the optimized structures correspond to equilibrium structures on their potential surfaces. Optimization and frequency calculations were performed using the Gaussian 09 program. ${ }^{28}$

The binding energy $(\Delta E)$ of a binary or a ternary complex is the difference between the energy of the complex and the sum of the energies of the corresponding isolated monomers at their equilibrium geometries. The cooperativity of binding energies $(\delta \Delta E)$ is the difference between the binding energy of a ternary complex and the sum of the binding energies of the corresponding binary complexes. It is also possible to analyze the binding energies of binary and ternary complexes using the many-body interactionenergy formalism (MBIE). ${ }^{29,30}$ For a ternary complex, $\Delta E$ can be decomposed into one-, two-, and three-body interactions.

$$
\begin{gathered}
\Delta E=E(A B C)-\sum_{i=A}^{C} E_{\mathrm{m}}(i) \\
=\sum_{i=A}^{C}\left[E(i)-E_{\mathrm{m}}(i)\right]+\sum_{i=A}^{B} \sum_{j>i}^{C} \Delta^{2} E(i j)+\Delta^{3} E(A B C) \\
E_{\mathrm{R}}(i)=E(i)-E_{\mathrm{m}}(i) \\
\Delta^{2} E(i j)=E(i j)-[E(i)+E(j)] \\
\Delta^{3} E(A B C)=E(A B C)-[E(A)+E(B)+E(C)]-\left[\Delta^{2} E(A B)+\Delta^{2} E(A C)\right. \\
\left.+\Delta^{2} E(B C)\right]
\end{gathered}
$$

$E_{\mathrm{m}}(i)$ is the energy of an isolated, optimized monomer, while $E(i)$ is the monomer energy at its geometry in the complex.
$E_{\mathrm{R}}(i)$ is the monomer distortion energy. $\Delta^{2} E(i j)$ and $\Delta^{3} E(A B C)$ are the two- and three-body interaction energies computed at the corresponding geometries in the complex.

The electron densities of complexes have been analyzed using the Atoms in Molecules (AIM) methodology ${ }^{31-34}$ employing the AIMAll $^{35}$ program. The topological analysis of the electron density produces the molecular graph of each complex. This graph identifies the location of electron density features of interest, including the electron density $(\rho)$ maxima associated with various nuclei, and saddle points which correspond to bond critical points (BCPs). The zero gradient line which connects a $\mathrm{BCP}$ with two nuclei is the bond path. The electron density at the BCP $\left(\rho_{\mathrm{BCP}}\right)$, the Laplacian of the electron density at the BCP $\left(\nabla^{2} \rho_{\mathrm{BCP}}\right)$, and the total energy density $\left(H_{\mathrm{BCP}}\right)$ are additional useful quantities for characterizing interactions. ${ }^{36}$

Molecular electrostatic potentials (MEPs) have been computed using the Multiwfn software. ${ }^{37}$ The NBO method ${ }^{38}$ has been used to compute MP2/aug'-cc-pVTZ atomic populations and chargetransfer interaction energies using the NBO-3.1 program. ${ }^{39}$ Since MP2 orbitals do not exist, charge-transfer energies were obtained using the B3LYP functional ${ }^{40,41}$ with the aug ${ }^{\prime}$-cc-pVTZ basis set at the MP2/aug'-cc-pVTZ geometries, so that at least some electron correlation effects could be included.

Spin-spin coupling constants were evaluated using the equation-of-motion coupled cluster singles and doubles (EOM-CCSD) method in the CI(configuration interaction)-like approximation, ${ }^{42,43}$ with all electrons correlated. For these calculations, the Ahlrichs ${ }^{44}$ qzp basis set was placed on ${ }^{13} \mathrm{C}$, ${ }^{15} \mathrm{~N}$, and ${ }^{19} \mathrm{~F}$, and the qz2p basis set on ${ }^{35} \mathrm{Cl}$. A basis set for ${ }^{9} \mathrm{Be}$ was developed using the same approach as used previously for ${ }^{7} \mathrm{Li}$ and ${ }^{11} \mathrm{~B} .{ }^{45}$ The Dunning cc-pVDZ basis set was placed on all ${ }^{1} \mathrm{H}$ atoms. All terms, namely, the paramagnetic spin-orbit (PSO), the diamagnetic spin orbit (DSO), the Fermi contact (FC), and the spin dipole (SD), have been evaluated for all but four complexes for which the calculation of all terms is not feasible. The EOM-CCSD calculations were performed using ACES $\mathrm{II}^{46}$ on the IBM Cluster 1350 (Glenn) at the Ohio Supercomputer Center.

\section{Results and discussion}

\section{Monomers and binary complexes}

The molecular electrostatic potential of FCl has a $\sigma$-hole with a value of 0.065 au along the symmetry axis of the molecule close to $\mathrm{Cl}$ and on the side opposite to the $\mathrm{F}$ atom. At the $\mathrm{F}$ atom there is a toroid of negative MEP values. The maximum and minimum values of the MEPs for all monomers are reported in Table S1 (ESI $\dagger$ ). These values change when $\mathrm{FCl}$ forms complexes with $\mathrm{BeH}_{2}$ and its derivatives, and when $\mathrm{FCl}$ forms halogen bonds with the nitrogen bases, as can be seen from the data of Table 1. Complexation with $\mathrm{BeH}_{2}$ and its derivatives leads to an increase in the positive values of the $\sigma$-holes in the order

$\mathrm{FCl}<\mathrm{HFBe}: \mathrm{FCl}(E) \approx \mathrm{H}_{2} \mathrm{Be}: \mathrm{FCl} \approx \mathrm{HFBe}: \mathrm{FCl}(Z)<\mathrm{F}_{2} \mathrm{Be}: \mathrm{FCl}<$ $\mathrm{Cl}_{2} \mathrm{Be}: \mathrm{FCl}$. 
Table 1 MEP maxima of sigma-holes at $\mathrm{Cl}$ and MEP minima (au) at $\mathrm{F}$ on the 0.001 electron density isosurfaces of $\mathrm{XYBe}: \mathrm{FCl}$ and $\mathrm{FCl}: \mathrm{N}$-base binary complexes

\begin{tabular}{llll}
\hline Moiety & MEP maxima at Cl & Moiety & MEP minima at F \\
\hline FCl & 0.065 & FCl & -0.012 \\
$\mathrm{H}_{2} \mathrm{Be}: \mathrm{FCl}$ & 0.083 & FCl:NCH & -0.032 \\
$\mathrm{HFBe}: \mathrm{FCl}(E)$ & 0.080 & FCl: $\mathrm{NH}_{3}$ & -0.052 \\
$\mathrm{HFBe}: \mathrm{FCl}(Z)$ & 0.085 & FCl: $\mathrm{NHCH}_{2}$ & -0.056 \\
$\mathrm{~F}_{2} \mathrm{Be}: \mathrm{FCl}$ & 0.091 & & \\
$\mathrm{Cl}_{2} \mathrm{Be}: \mathrm{FCl}$ & 0.096 & & \\
\hline
\end{tabular}

In addition, the MEP minima associated with fluorine become more negative in the binary complexes with nitrogen bases, and increase in absolute values in the order

$$
\mathrm{FCl}<\mathrm{FCl}: \mathrm{NCH}<\mathrm{FCl}: \mathrm{NH}_{3} \approx \mathrm{FCl}: \mathrm{NHCH}_{2} .
$$

MEPs for $\mathrm{FCl}, \mathrm{Cl}_{2} \mathrm{Be}: \mathrm{FCl}$, and $\mathrm{FCl}: \mathrm{NH}_{3}$ are illustrated in Fig. 1. Thus, complexation of $\mathrm{FCl}$ with $\mathrm{BeH}_{2}$ and its derivatives makes FCl a stronger electron-pair acceptor for the formation of halogen bonds with the nitrogen bases, while complexation with the nitrogen bases makes $\mathrm{FCl}$ a better electron-pair donor to the beryllium acids. Hence, when FCl interacts simultaneously with the beryllium derivatives and the nitrogen bases, synergistic cooperativity between the beryllium bond and the halogen bond should be expected, as has been observed for other weak interactions. ${ }^{47,48}$

The structures, total energies, and molecular graphs of the binary complexes are reported in Table S2 of the ESI, $\dagger$ and their binding energies in Table 2. In complexes of FCl with the beryllium derivatives, binding energies range from -8.5 to $-16.0 \mathrm{~kJ} \mathrm{~mol}^{-1}$, and increase in the order

$$
\begin{gathered}
\text { HFBe:FCl }(E)<\mathrm{H}_{2} \text { Be:FCl } \approx \text { HFBe: } \mathrm{FCl}(Z)<\mathrm{Cl}_{2} \mathrm{Be}: \mathrm{FCl}< \\
\mathrm{F}_{2} \text { Be:FCl. }
\end{gathered}
$$

Binding energies are much greater in the binary complexes between $\mathrm{FCl}$ and the nitrogen bases, varying from -24.5 to $-51.2 \mathrm{~kJ} \mathrm{~mol}^{-1}$, and increasing in the order $\mathrm{FCl}: \mathrm{NCH} \ll$ $\mathrm{FCl}: \mathrm{NH}_{3} \approx \mathrm{FCl}: \mathrm{NHCH}_{2}$.

What are the structural and bonding characteristics that correlate with these binding energies? From Table 2 it can be seen that complexation of $\mathrm{BeH}_{2}$ and its derivatives with the electron-donor FCl leads to a bending of the XYBe molecule as

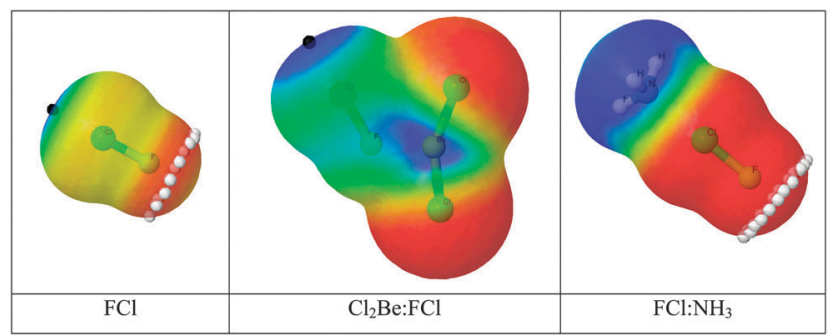

Fig. 1 MEPs on the 0.001 electron density isosurfaces. Color coding corresponds to $-0.015 \mathrm{au}=$ red $<$ yellow $<$ green $<$ blue $=0.05 \mathrm{au}$. The $\mathrm{Cl} \sigma$-holes and the MEP minima at $\mathrm{F}$ are indicated with black and white dots, respectively.
Table 2 Binding energies $\left(\Delta E, \mathrm{~kJ} \mathrm{~mol}^{-1}\right), \mathrm{X}-\mathrm{Be}-\mathrm{Y}$ angles $(<, \mathrm{deg})$, and $\mathrm{Be} \cdots \mathrm{F}, \mathrm{F}-\mathrm{Cl}$, and $\mathrm{Cl} \cdots \mathrm{N}$ distances $(R, \AA)$ in binary complexes $\mathrm{XYBe}: \mathrm{FCl}$ and $\mathrm{FCl}: \mathrm{N}$-base

\begin{tabular}{lccccc}
\hline & $\Delta E$ & $<\mathrm{X}-\mathrm{Be}-\mathrm{Y}^{a}$ & $(\mathrm{Be} \cdots \mathrm{F})$ & $R(\mathrm{~F}-\mathrm{Cl})$ & $R(\mathrm{Cl} \cdots \mathrm{N})$ \\
\hline FCl monomer & & & & 1.638 & \\
Complexes & & & & & \\
$\mathrm{H}_{2} \mathrm{Be}: \mathrm{FCl}$ & -9.5 & 164 & 2.061 & 1.656 & \\
HFBe:FCl $(E)$ & -8.5 & 168 & 2.286 & 1.645 & \\
HFBe:FCl $(Z)$ & -9.8 & 163 & 2.096 & 1.656 & \\
$\mathrm{~F}_{2} \mathrm{Be}: \mathrm{FCl}$ & -16.0 & 158 & 1.979 & 1.665 & \\
$\mathrm{Cl}_{2} \mathrm{Be}: \mathrm{FCl}$ & -14.9 & 152 & 1.900 & 1.665 & \\
& & & & & \\
FCl:NCH & -24.5 & & & 1.656 & 2.542 \\
FCl: $\mathrm{NH}_{3}$ & -49.1 & & & 1.714 & 2.235 \\
FCl:NHCH & -51.2 & & & 1.721 & 2.161
\end{tabular}

${ }^{a}$ The bond angle in $\mathrm{BeH}_{2}$ and its derivatives. The isolated molecules are linear.

the intramolecular $\mathrm{X}-\mathrm{Be}-\mathrm{Y}$ angle decreases from $180^{\circ}$ in the monomers to between $168^{\circ}$ in $\operatorname{HFBe} \operatorname{FCl}(E)$ and $152^{\circ}$ in $\mathrm{Cl}_{2} \mathrm{Be}$ :FCl. The bending of these molecules is a result of charge transfer from the $\mathrm{F}$ lone pairs primarily to the empty $\mathrm{p}(\sigma)$ orbital of XYBe, and signals a change in the Be hybridization. Fig. 2 illustrates the good second-order correlation between the $\mathrm{X}-\mathrm{Be}-\mathrm{Y}$ angle and the NBO second-order stabilization energy arising from charge transfer from the $\mathrm{F}$ lone pairs to the empty $\mathrm{p}(\sigma)$ orbital of beryllium, with a correlation coefficient $R^{2}$ of 0.976. The $\mathrm{F}-\mathrm{Cl}$ distance tends to increase and the $\mathrm{Be} \cdot \mathrm{F}$ distance decreases as the interaction between the Be derivative and FCl becomes stronger. Tables S3 and S4, respectively, of the $\mathrm{ESI} \dagger$ indicate that the electron densities at Be $\cdots \mathrm{F}$ BCPs are largest and NBO bond orders are greatest in the two most strongly bound complexes, $\mathrm{Cl}_{2} \mathrm{Be}: \mathrm{FCl}$ and $\mathrm{F}_{2} \mathrm{Be}: \mathrm{FCl}$, while the electron densities at the $\mathrm{F}-\mathrm{Cl}$ BCPs are depleted and the NBO bond orders reduced in the binary complexes relative to isolated $\mathrm{FCl}$. The lengthening of the $\mathrm{F}-\mathrm{Cl}$ bond is even greater in the binary complexes of FCl with the nitrogen bases, with the weakest and longest $\mathrm{F}-\mathrm{Cl}$ bonds occurring in the complexes of FCl with $\mathrm{NH}_{3}$ and $\mathrm{NHCH}_{2}$. However, the halogen bonds in these binary complexes are still characterized as traditional halogen bonds. ${ }^{6}$

The binding energies of Table 2 indicate that $\mathrm{HFBe}: \operatorname{FCl}(Z)$ is more stable than HFBe: $\mathrm{FCl}(E)$. This ordering is consistent with the shorter Be-F distance and the greater bending of the HFBe molecule in the $Z$ isomer compared to $E$. In addition, even though the MBIE analyses of Table S5 (ESI $\dagger$ ) indicate that the stabilizing second-order interaction energy of $\mathrm{Cl}_{2} \mathrm{Be}: \mathrm{FCl}$ is greater than that of $\mathrm{F}_{2} \mathrm{Be}: \mathrm{FCl}$, the destabilizing distortion energies of the monomers are even greater in the former, with the result that the binding energy of $\mathrm{F}_{2} \mathrm{Be}: \mathrm{FCl}$ is greater than that of $\mathrm{Cl}_{2} \mathrm{Be}: \mathrm{FCl}$. In contrast, in complexes between $\mathrm{FCl}$ and the nitrogen bases, the distortion energies of $\mathrm{FCl}$ are greater than those of the nitrogen bases. The largest distortion energies are found for the complex $\mathrm{FCl}: \mathrm{NHCH}_{2}$. As a result, although the NBO second-order energy of this complex is $5 \mathrm{~kJ} \mathrm{~mol}^{-1}$ greater than that of $\mathrm{FCl}: \mathrm{NH}_{3}$, its binding energy is only $2 \mathrm{~kJ} \mathrm{~mol}^{-1}$ greater. 




Fig. 2 NBO second-order charge-transfer stabilization energy $[F(l p) \rightarrow$ $\mathrm{p}(\sigma) \mathrm{Be}]$ versus the $\mathrm{X}-\mathrm{Be}-\mathrm{Y}$ angle for complexes $\mathrm{XYBe}: \mathrm{FCl}$.

\section{Ternary complexes}

Fifteen equilibrium ternary complexes with intermolecular $\mathrm{Be} \cdot \mathrm{F}$ and $\mathrm{Cl} \cdots \mathrm{N}$ bonds can be formed from the three bases $\mathrm{NCH}, \mathrm{NH}_{3}$, and $\mathrm{NHCH}_{2}$ and the four acids $\mathrm{BeH}_{2}, \mathrm{BeHF}, \mathrm{BeF}_{2}$, and $\mathrm{BeCl}_{2}$, since there are two different conformers for complexes of BeHF with each base. Table $\mathrm{S} 2$ of the ESI $\dagger$ provides the structures, total energies, and molecular graphs of these complexes, Fig. 3 illustrates the structures of four representative ternary complexes, and Table 3 reports intra- and intermolecular distances and $\mathrm{X}-\mathrm{Be}-\mathrm{Y}$ angles. The structures of these complexes are consistent with anticipated interactions between complementary MEP regions of the corresponding isolated monomers.

The data of Table 3 illustrate that $\mathrm{Be} \cdots \mathrm{F}$ and $\mathrm{Cl} \cdots \mathrm{N}$ intermolecular distances dramatically decrease in the ternary complexes relative to the corresponding binary complexes. The decrease in the Be $\cdots \mathrm{F}$ distance ranges from 0.28 to $0.71 \AA$, while the decrease in the $\mathrm{Cl} \cdots \mathrm{N}$ distance ranges from 0.32 to $0.80 \AA$. In the same complexes, the $\mathrm{F}-\mathrm{Cl}$ distance increases and is longer than it is in any binary complex, and therefore significantly longer than in the isolated FCl molecule. These distance changes are reflected in increased NBO bond orders



$\mathrm{F}_{2} \mathrm{Be}: \mathrm{FCl}: \mathrm{NH}_{3}$



HFBe:FCl:NCH $(E)$

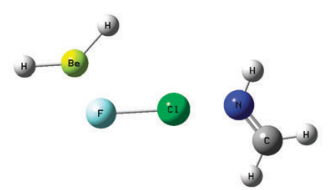

$\mathrm{H}_{2} \mathrm{Be}: \mathrm{FCl}: \mathrm{NHCH}_{2}$

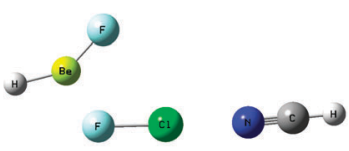

HFBe:FCl:NCH $(Z)$

Fig. 3 Ternary complexes $\mathrm{H}_{2} \mathrm{Be}: \mathrm{FCl}: \mathrm{NH}_{3}, \mathrm{~F}_{2} \mathrm{Be}: \mathrm{FCl}: \mathrm{NHCH}_{2}$, and HFBe: $\mathrm{FCl}: \mathrm{NCH}$ with $E$ and $Z$ conformations. reported in Table S4 (ESI $\dagger$ ) for the $\mathrm{Be} \cdots \mathrm{F}$ and $\mathrm{Cl} \cdots \mathrm{N}$ bonds, and the decreased NBO bond orders for $\mathrm{F}-\mathrm{Cl}$ bonds. In addition, electron densities at $\mathrm{Be} \cdots \mathrm{F}$ and $\mathrm{Cl} \cdots \mathrm{F}$ BCPs are more than three times greater in the ternary complexes than in the corresponding binary complexes. An exponential relationship exists between these densities and the corresponding distances, as is usually the case for intermolecular interactions. ${ }^{49-57}$ These relationships have correlation coefficients greater than 0.99 . Changes in the Be. $\cdot \mathrm{F}$ distances are accompanied by a further decrease in the $\mathrm{X}-\mathrm{Be}-\mathrm{Y}$ bond angles to between $147^{\circ}$ in $\mathrm{H}_{2} \mathrm{Be}: \mathrm{FCl}: \mathrm{NCH}$ and $126^{\circ}$ in the two most strongly bound complexes, $\mathrm{Cl}_{2} \mathrm{Be}: \mathrm{FCl}: \mathrm{NH}_{3}$ and $\mathrm{Cl}_{2} \mathrm{Be}: \mathrm{FCl}: \mathrm{NHCH}_{2}$. Thus, it is apparent that the hybridization of Be approaches $\mathrm{sp}^{2}$ in these complexes. The data of Table S4 (ESI $\dagger$ ) indicate that there is a dramatic increase in the $\mathrm{Be} \cdots \mathrm{F}$ and $\mathrm{Cl} \cdots \mathrm{F}$ bond orders along with a decrease in the $\mathrm{F}-\mathrm{Cl}$ bond order in ternary complexes. For a given base, the $\mathrm{Be} \cdots \mathrm{F}$ and $\mathrm{Cl} \cdots \mathrm{F}$ bond orders increase in the order $\mathrm{H}_{2} \mathrm{Be} \approx \mathrm{HFBe}<\mathrm{F}_{2} \mathrm{Be}: \mathrm{FCl}<\mathrm{Cl}_{2} \mathrm{Be}$ :FCl, while the $\mathrm{F}-\mathrm{Cl}$ bond orders decrease in the same order.

These huge structural changes are associated with very strong cooperative effects between the beryllium and halogen bonds, which were anticipated from the increased positive values of the $\sigma$-holes at $\mathrm{Cl}$ in XYBe:FCl complexes, and the increased negative values of the MEPs at F in FCl:N-base complexes. The binding energies reported in Table 4 range from -50 to $-200 \mathrm{~kJ} \mathrm{~mol}^{-1}$, while the nonadditivity of binding energies varies from about $-20 \mathrm{~kJ} \mathrm{~mol}^{-1}$ for the more weaklybound complexes with $\mathrm{NCH}$, to $-135 \mathrm{~kJ} \mathrm{~mol}^{-1}$ for $\mathrm{Cl}_{2} \mathrm{Be}: \mathrm{FCl}: \mathrm{NHCH}_{2}$. As expected, the variation in the three-body energies is much greater, from $-30 \mathrm{~kJ} \mathrm{~mol}^{-1}$ for $\mathrm{H}_{2} \mathrm{Be}: \mathrm{FCl}: \mathrm{NCH}$ to $-219 \mathrm{~kJ} \mathrm{~mol}^{-1}$ for $\mathrm{Cl}_{2} \mathrm{Be}: \mathrm{FCl}: \mathrm{NHCH}_{2}$. The order of increasing binding energies and nonadditivities with respect to the beryllium derivatives is

$$
\text { BeHF, } \mathrm{BeH}_{2}<\mathrm{BeF}_{2}<\mathrm{BeCl}_{2}
$$

while the order with respect to the bases is

$$
\mathrm{NCH} \ll \mathrm{NH}_{3}<\mathrm{NHCH}_{2} .
$$

Fig. 4 illustrates the excellent linear correlation between cooperative effects as measured by $\delta \Delta E$ and the binding energies of the ternary complexes, with a correlation coefficient of 0.992 . It should also be noted that Table S5 (ESI $\dagger$ ) indicates that although the total destabilizing monomer distortion energies of the $\mathrm{BeCl}_{2}$ ternary complexes are greater than those of the corresponding $\mathrm{BeF}_{2}$ ternary complexes, the sum of the stabilizing two- and threebody interaction energies in the $\mathrm{BeCl}_{2}$ complexes is even greater, with the result that the ternary complexes containing $\mathrm{BeCl}_{2}$ are now much more stable than the corresponding $\mathrm{BeF}_{2}$ complexes.

Given the large binding energies and cooperative effects in these complexes, it would be expected that the charge-transfer energies would also increase. Unfortunately, it is not possible to compute these energies since the NBO program does not describe the ternary complexes as containing three identifiable monomers. However, based on the relationship between the $\mathrm{X}-\mathrm{Be}-\mathrm{Y}$ angles in the binary complexes and their charge-transfer 
Table 3 MP2/aug'-cc-pVTZ distances $(\AA)$ and $\mathrm{X}-\mathrm{Be}-\mathrm{Y}$ bond angles ( $\angle \mathrm{XBeY}$, degrees) for ternary complexes and changes in these variables $(\delta)$ relative to the corresponding binary complexes

\begin{tabular}{|c|c|c|c|c|c|c|c|}
\hline Complexes & $\mathrm{Be} \cdots \mathrm{F}$ & $\delta \mathrm{Be} \cdots \mathrm{F}$ & $\mathrm{F}-\mathrm{Cl}^{a}$ & $\mathrm{Cl} \cdots \mathrm{N}$ & $\delta \mathrm{Cl} \cdots \mathrm{N}$ & $\angle \mathrm{XBeY}$ & $\delta \angle \mathrm{XBeY}$ \\
\hline HFBe:FCl:NH ${ }_{3}(E)$ & 1.609 & -0.677 & 1.927 & 1.905 & -0.330 & 134 & -34 \\
\hline $\mathrm{Cl}_{2} \mathrm{Be}: \mathrm{FCl}: \mathrm{NH}_{3}$ & 1.530 & -0.370 & 2.043 & 1.832 & -0.403 & 126 & -26 \\
\hline $\mathrm{H}_{2} \mathrm{Be}: \mathrm{FCl}: \mathrm{NHCH}_{2}$ & 1.580 & -0.482 & 1.991 & 1.789 & -0.372 & 134 & -30 \\
\hline $\mathrm{F}_{2} \mathrm{Be}: \mathrm{FCl}: \mathrm{NHCH}_{2}$ & 1.566 & -0.413 & 2.043 & 1.762 & -0.399 & 130 & -28 \\
\hline $\mathrm{Cl}_{2} \mathrm{Be}: \mathrm{FCl}: \mathrm{NHCH}_{2}$ & 1.511 & -0.389 & 2.135 & 1.727 & -0.434 & 126 & -26 \\
\hline $\mathrm{H}_{2} \mathrm{Be}: \mathrm{FCl}: \mathrm{NCH}$ & 1.738 & -0.324 & 1.735 & 2.173 & -0.368 & 147 & -17 \\
\hline HFBe:FCl:NCH $(E)$ & 1.763 & -0.523 & 1.733 & 2.166 & -0.375 & 146 & -22 \\
\hline HFBe:FCl:NCH( $(Z)$ & 1.734 & -0.362 & 1.745 & 2.142 & -0.399 & 145 & -18 \\
\hline $\mathrm{F}_{2} \mathrm{Be}: \mathrm{FCl}: \mathrm{NCH}$ & 1.696 & -0.283 & 1.771 & 2.047 & -0.494 & 141 & -17 \\
\hline
\end{tabular}

Table 4 Binding energies $(\Delta E)$, cooperativity $(\delta \Delta E)$, and three-body interaction energies $\left(\Delta^{3} E, \mathrm{~kJ} \mathrm{~mol}^{-1}\right)$ of ternary complexes XYBe:FCl:N-base

\begin{tabular}{lccc}
\hline Complex & $\Delta E$ & $\delta \Delta E^{a}$ & $\Delta^{3} E(A B C)^{b}$ \\
\hline $\mathrm{H}_{2} \mathrm{Be}: \mathrm{FCl}: \mathrm{NH}_{3}$ & -129.9 & -71.3 & -100.7 \\
$\mathrm{HFBe}: \mathrm{FCl}: \mathrm{NH}_{3}(E)$ & -129.4 & -71.8 & -116.0 \\
$\mathrm{HFBe}: \mathrm{FCl}: \mathrm{NH}_{3}(Z)$ & -134.5 & -75.6 & -107.8 \\
$\mathrm{~F}_{2} \mathrm{Be}: \mathrm{FCl}: \mathrm{NH}_{3}$ & -152.8 & -87.7 & -136.0 \\
$\mathrm{Cl}_{2} \mathrm{Be}: \mathrm{FCl}: \mathrm{NH}_{3}$ & -178.2 & -114.2 & -178.8 \\
$\mathrm{H}_{2} \mathrm{Be}: \mathrm{FCl}: \mathrm{NHCH}_{2}$ & -145.5 & -84.8 & -127.4 \\
$\mathrm{HFBe}: \mathrm{FCl}: \mathrm{NHCH}_{2}(E)$ & -146.0 & -86.3 & -148.9 \\
$\mathrm{HFBe}: \mathrm{FCl}: \mathrm{NHCH}_{2}(Z)$ & -151.0 & -90.0 & -136.2 \\
$\mathrm{~F}_{2} \mathrm{Be}: \mathrm{FCl}: \mathrm{NHCH}_{2}$ & -171.2 & -104.0 & -172.2 \\
$\mathrm{Cl}_{2} \mathrm{Be}: \mathrm{FCl}: \mathrm{NHCH}_{2}$ & -201.3 & -135.2 & -219.0 \\
$\mathrm{H}_{2} \mathrm{Be}: \mathrm{FCl}: \mathrm{NCH}$ & -53.5 & -19.5 & -30.1 \\
$\mathrm{HFBe}: \mathrm{FCl}: \mathrm{NCH}(E)$ & -51.5 & -18.5 & -32.5 \\
$\mathrm{HFBe}: \mathrm{FCl}: \mathrm{NCH}(Z)$ & -54.6 & -20.3 & -33.7 \\
$\mathrm{~F}_{2} \mathrm{Be}: \mathrm{FCl}: \mathrm{NCH}$ & -67.8 & -27.0 & -51.8 \\
$\mathrm{Cl}_{2} \mathrm{Be}: \mathrm{FCl}: \mathrm{NCH}$ & -82.4 & -43.0 & -145.7
\end{tabular}

${ }^{a}$ The cooperativity computed as the binding energy of the ternary complex minus the binding energies of the two corresponding binary complexes (XYBe:FCl and FCl:N-base). ${ }^{b}$ The MBIE three-body interaction energy.

energies, it may be anticipated that further decreases in this angle in the ternary complexes indicate a further hybridization change at Be due to increased charge-transfer from $\mathrm{F}$ to the $\mathrm{Be}$ $\mathrm{p}(\sigma)$ orbital. This charge transfer strengthens the Be $\cdots \mathrm{F}$ and $\mathrm{Cl} \cdots \mathrm{N}$ bonds while weakening the $\mathrm{F}-\mathrm{Cl}$ bond by depopulating its $\mathrm{F}-\mathrm{Cl}$ density. In complexes with the stronger bases, depopulation effects are so large that the $\mathrm{F}-\mathrm{Cl}$ bond dissociates and the complex becomes an ion-pair $[\mathrm{XBeY}-\mathrm{F}]^{-} \ldots[\mathrm{Cl}-\mathrm{N}-\mathrm{base}]^{+}$. The $\mathrm{X}-\mathrm{Be}-\mathrm{Y}$ angles in $[\mathrm{XBeY}-\mathrm{F}]^{-}$are between 119 and $123^{\circ}$, indicating $\mathrm{sp}^{2}$ hybridization of Be. The mechanism for the formation of this ion-pair is the same as that for the well-known phenomenon of dissociative proton attachment ${ }^{58}$ in which gas-phase protonation of compounds like fluoro- or chloro-adamantane results in the spontaneous loss of $\mathrm{FH}$ or $\mathrm{ClH}$ and the formation of adamantyl cations.



Fig. 4 Cooperativity $(\delta \Delta E)$ versus the binding energy $(\Delta E)$ of ternary complexes XYBe:FCl:N-base.

The NBO description of $\mathrm{Cl}_{2} \mathrm{Be}: \mathrm{FCl}: \mathrm{NHCH}_{2}$ has natural charges close to -1 and +1 on $\mathrm{Cl}_{2} \mathrm{BeF}$ and $\mathrm{Cl}$ : $\mathrm{NHCH}_{2}$, respectively $( \pm 0.84)$. The Be-F distance of $1.511 \AA$ and the $\mathrm{Cl}-\mathrm{N}$ distance of $1.727 \AA$ in this complex approach the Be-F distance of $1.446 \AA$ in the anion $\left[\mathrm{Cl}_{2} \mathrm{Be}-\mathrm{F}\right]^{-}$and the $\mathrm{Cl}-\mathrm{N}$ distance of $1.686 \AA$ in the cation $\left[\mathrm{ClNHCH}_{2}\right]^{+}$. Dissociation of $\mathrm{Cl}_{2} \mathrm{Be}$ :FCl: $\mathrm{NHCH}_{2}$ to the two ions requires only $338 \mathrm{~kJ} \mathrm{~mol}^{-1}$, whereas the heterolytic dissociation of $\mathrm{FCl}$ into $\mathrm{F}^{-}$and $\mathrm{Cl}^{+}$ requires $1311 \mathrm{~kJ} \mathrm{~mol}^{-1}$. The structures and bonding properties of the complexes XYBe:FCl:N-base indicate that interaction of $\mathrm{Be} \cdot \mathrm{F}$ beryllium bonds with $\mathrm{Cl} \cdots \mathrm{N}$ halogen bonds leads to an evolution of the halogen-bond type, from traditional to chlorine-shared to ion-pair bonds. This evolution occurs smoothly as a function of the intrinsic basicity of the nitrogen base and the intrinsic acidity of the beryllium derivative.

\section{Spin-spin coupling constants}

The components of spin-spin coupling constants for the FCl monomer, the binary and ternary complexes, and the corresponding ions are reported in Table S6 of the ESI. $\dagger$ Since the 
calculation of EOM-CCSD coupling constants for $\mathrm{F}_{2} \mathrm{Be}$ :FCl: $\mathrm{NHCH}_{2}$ and ternary complexes with $\mathrm{BeCl}_{2}$ as the beryllium acid are not feasible, the first question is whether or not the FC terms are good approximations to total $J$. Table S6 (ESI $\dagger$ ) indicates that the FC term does provide a good approximation to the total coupling constant ${ }^{1 \mathrm{be}} J(\mathrm{Be}-\mathrm{F})$ in the binary complexes and the ternary complexes with $\mathrm{NCH}$ as the base. However, it is usually not a good approximation for ternary complexes with $\mathrm{NH}_{3}$ and $\mathrm{NHCH}_{2}$ in which the Be $\cdots \mathrm{F}$ distance is shorter, and in all of the cations, even though the FC term is the dominant term in all but two of these. The FC term is a poor approximation to total ${ }^{1} J(\mathrm{~F}-\mathrm{Cl})$ due to non-negligible contributions from both PSO and DSO terms. Indeed, for all of the binary complexes and the ternary complexes with $\mathrm{NCH}$ as the base, the FC term is not even the dominant term. The FC term is a reasonable approximation to ${ }^{1 \mathrm{X}} \mathrm{J}(\mathrm{Cl}-\mathrm{N})$ for the binary complexes, the ternary complexes with $\mathrm{NCH}$ as the base, and the cation ${ }^{+} \mathrm{Cl}-\mathrm{NCH}$. However, it is not a good approximation for ternary complexes with the stronger nitrogen bases and the corresponding cations. Therefore, the following discussion of coupling constants is based only on total $J$ values and trends. The Be $\cdots \mathrm{F}$ coupling constant across the beryllium bond is denoted ${ }^{1 \mathrm{be}} J(\mathrm{Be}-\mathrm{F})$, while that across the halogen bond is ${ }^{1 \mathrm{X}} J(\mathrm{Cl}-\mathrm{N})$. These designations will be used throughout the following discussion, even when these bonds lose their intermolecular character and are better described as ${ }^{1} J$ values.

${ }^{1 \mathbf{b e}} J(\mathbf{B e}-\mathbf{F})$. Table 5 reports Be-F distances and values of the Be-F coupling constants for binary complexes with all acids, ternary complexes with the acids $\mathrm{H}_{2} \mathrm{Be}$, $\mathrm{HFBe}$, and $\mathrm{BeF}_{2}$, and the anions $\mathrm{XYBeF}^{-}$. Since the $\mathrm{FC}$ terms were computed for all ternary complexes, they are also given for comparison. The data in Table 5 are reported for a fixed acid, first for the binary $\mathrm{XYBe}: \mathrm{FCl}$ complex, then for the ternary complexes in the order $\mathrm{NCH}, \mathrm{NH}_{3}, \mathrm{NHCH}_{2}$, and finally for the corresponding anion $\mathrm{XYBeF}^{-}$. While the Be-F distance decreases in going from the binary complexes with $\mathrm{H}_{2} \mathrm{Be}$ and $\mathrm{HFBe}$ to the corresponding ternary complexes with the weak base $\mathrm{NCH}$, coupling constants ${ }^{1 b e} J(B e-F)$ initially increase, but subsequently decrease and change sign as the base strength increases. ${ }^{1 \mathrm{be}} J(\mathrm{Be}-\mathrm{F})$ is negative for all ternary complexes with $\mathrm{BeF}_{2}$.

Fig. 5 provides a plot of ${ }^{1 \mathrm{be}} J(\mathrm{Be}-\mathrm{F})$ versus the Be-F distance for ternary complexes with $\mathrm{BeH}_{2}$, BeHF, and $\mathrm{BeF}_{2}$. For each acid, the point at the longest distance corresponds to the ternary complex with $\mathrm{HCN}$, and that at the shortest distance to the corresponding anion $\mathrm{XYBeF}^{-}$. The correlation coefficients $R^{2}$ are $0.999,0.966$, and 1.000 , the latter with only three points. Thus, ${ }^{1 \mathrm{be}} J(\mathrm{Be}-\mathrm{F})$ values for these ternary complexes decrease with decreasing $\mathrm{Cl}-\mathrm{N}$ distance, and approach ${ }^{1 \mathrm{be}} J(\mathrm{Be}-\mathrm{F})$ for the corresponding anions as the Be-F distance decreases.

${ }^{1} \boldsymbol{J}(\mathbf{F}-\mathbf{C l})$. Table 6 reports the FC terms and ${ }^{1} J(\mathrm{~F}-\mathrm{Cl})$ for the binary complexes XYBe:FCl and $\mathrm{FCl}: \mathrm{N}-\mathrm{base}$, and the ternary complexes XYBe:FCl:N-base. Upon formation of a Be $\cdots \mathrm{F}$ bond in the binary complexes with BeXY, this coupling constant decreases from its monomer value of $798 \mathrm{~Hz}$ to $768 \mathrm{~Hz}$ in $\mathrm{Cl}_{2} \mathrm{Be}: \mathrm{FCl}$. The decrease is much greater in the binary
Table 5 Be-F distances ( $\AA$ ), and $\mathrm{FC}$ terms and ${ }^{1 \mathrm{be}} \mathrm{J}(\mathrm{Be}-\mathrm{F})(\mathrm{Hz})$ for binary complexes $\mathrm{XYBe}: \mathrm{FCl}$, ternary complexes XYBe:FCl:N-base, and ions $[\mathrm{XYBeF}]^{-}$

\begin{tabular}{|c|c|c|c|}
\hline Complex & FC & ${ }^{1 \mathrm{be}} J(\mathrm{Be}-\mathrm{F})$ & $R(\mathrm{Be}-\mathrm{F})$ \\
\hline $\mathrm{H}_{2} \mathrm{Be}: \mathrm{FCl}$ & 22.2 & 22.9 & 2.061 \\
\hline $\mathrm{H}_{2} \mathrm{Be}: \mathrm{FCl}: \mathrm{NCH}$ & 36.7 & 39.0 & 1.738 \\
\hline $\mathrm{H}_{2} \mathrm{Be}: \mathrm{FCl}: \mathrm{NH}_{3}$ & 12.6 & 16.5 & 1.607 \\
\hline $\mathrm{H}_{2} \mathrm{Be}: \mathrm{FCl}: \mathrm{NHCH}_{2}$ & 4.6 & 8.9 & 1.580 \\
\hline $\mathrm{H}_{2} \mathrm{BeF}^{-}$ & -28.3 & -21.4 & 1.485 \\
\hline HFBe:FCl $(E)$ & 12.5 & 12.6 & 2.286 \\
\hline HFBe:FCl:NCH & 23.6 & 24.9 & 1.764 \\
\hline HFBe:FCl: $\mathrm{NH}_{3}$ & -1.8 & 1.0 & 1.609 \\
\hline HFBe:FCl:NHCH ${ }_{2}$ & -9.2 & -5.9 & 1.579 \\
\hline $\mathrm{HBeF}_{2}^{-}$ & -37.4 & -32.0 & 1.484 \\
\hline HFBe:FCl( $Z)$ & 25.7 & 26.1 & 2.096 \\
\hline HFBe:FCl:NCH & 33.4 & 34.9 & 1.734 \\
\hline HFBe:FCl:NH ${ }_{3}$ & 4.4 & 7.3 & 1.603 \\
\hline HFBe:FCl:NHCH ${ }_{2}$ & -4.8 & -1.5 & 1.575 \\
\hline $\mathrm{HBeF}_{2}^{-}$ & -37.4 & -32.0 & 1.484 \\
\hline $\mathrm{F}_{2} \mathrm{Be}: \mathrm{FCl}$ & 8.7 & 9.0 & 1.979 \\
\hline $\mathrm{F}_{2} \mathrm{Be}: \mathrm{FCl}: \mathrm{NCH}$ & -9.9 & -8.8 & 1.696 \\
\hline $\mathrm{F}_{2} \mathrm{Be}: \mathrm{FCl}: \mathrm{NH}_{3}$ & -29.8 & -27.7 & 1.591 \\
\hline $\mathrm{F}_{2} \mathrm{Be}: \mathrm{FCl}: \mathrm{NHCH}_{2}$ & -35.8 & & 1.566 \\
\hline $\mathrm{F}_{2} \mathrm{BeF}^{-}$ & -57.3 & -53.1 & 1.485 \\
\hline $\mathrm{Cl}_{2} \mathrm{Be}: \mathrm{FCl}$ & 23.3 & 23.9 & 1.900 \\
\hline $\mathrm{Cl}_{2} \mathrm{Be}: \mathrm{FCl}: \mathrm{NCH}$ & -23.8 & & 1.553 \\
\hline $\mathrm{Cl}_{2} \mathrm{Be}: \mathrm{FCl}: \mathrm{NH}_{3}$ & -30.6 & & 1.530 \\
\hline $\mathrm{Cl}_{2} \mathrm{Be}: \mathrm{FCl}: \mathrm{NHCH}_{2}$ & -36.4 & & 1.511 \\
\hline $\mathrm{Cl}_{2} \mathrm{BeF}^{-}$ & -55.6 & -49.5 & 1.446 \\
\hline
\end{tabular}

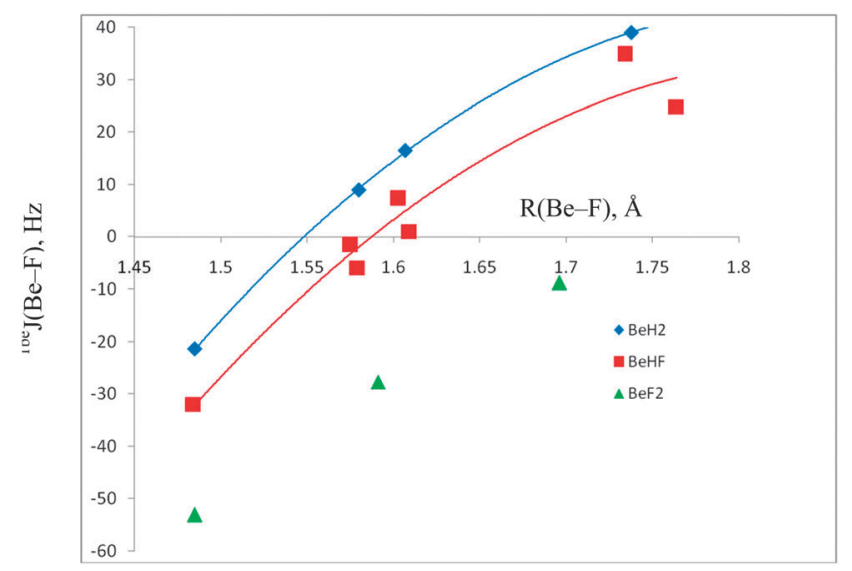

Fig. $5{ }^{1 \mathrm{be}} \mathrm{J}(\mathrm{Be}-\mathrm{F})$ versus the $\mathrm{Be}-\mathrm{F}$ distance for ternary complexes with $\mathrm{BeH}_{2}, \mathrm{BeHF}$ and $\mathrm{BeF}_{2}$ as the acids, and the corresponding anions $\mathrm{BeH}_{2} \mathrm{~F}^{-}$, $\mathrm{BeHF}_{2}{ }^{-}$and $\mathrm{BeF}_{3}{ }^{-}$.

complexes with the nitrogen bases, with values of 753,694 , and $680 \mathrm{~Hz}$ for $\mathrm{FCl}: \mathrm{NCH}, \mathrm{FCl}: \mathrm{NH}_{3}$, and $\mathrm{FCl}: \mathrm{NHCH}_{2}$, respectively. These decreases reflect the lengthening of the $\mathrm{F}-\mathrm{Cl}$ bonds in the binary complexes.

In the ternary complexes, the decrease in ${ }^{1} J(\mathrm{~F}-\mathrm{Cl})$ is even greater, with ${ }^{1} J(\mathrm{~F}-\mathrm{Cl})$ values ranging from $663 \mathrm{~Hz}$ in $\mathrm{H}_{2} \mathrm{Be}: \mathrm{FCl}: \mathrm{NCH}$ to $473 \mathrm{~Hz}$ in HFBe:FCl: $\mathrm{NHCH}_{2}(Z)$. The range of ${ }^{1} J(\mathrm{~F}-\mathrm{Cl})$ values would probably be even greater if data for ternary complexes with $\mathrm{Cl}_{2} \mathrm{Be}$ were available. For a fixed base, ${ }^{1} J(\mathrm{~F}-\mathrm{Cl})$ in ternary complexes decreases in the order 
Table $6 \mathrm{FC}$ terms and ${ }^{1} \mathrm{~J}(\mathrm{~F}-\mathrm{Cl})$ and ${ }^{1 \times} \mathrm{J}(\mathrm{Cl}-\mathrm{N})(\mathrm{Hz})$ for binary complexes $\mathrm{FCl}: \mathrm{N}$-base, ternary complexes $\mathrm{XYBe}: \mathrm{FCl}: \mathrm{N}$-base, and ions ${ }^{+} \mathrm{Cl}-\mathrm{N}$-base

\begin{tabular}{|c|c|c|c|c|}
\hline Moiety & FC & ${ }^{1} J(\mathrm{~F}-\mathrm{Cl})$ & FC & ${ }^{1 \mathrm{X}} J(\mathrm{Cl}-\mathrm{N})$ \\
\hline $\mathrm{FCl}$ & -99.4 & 798.0 & & \\
\hline $\mathrm{H}_{2} \mathrm{Be}: \mathrm{FCl}$ & -94.4 & 784.4 & & \\
\hline HFBe:FCl $(E)$ & -97.0 & 788.1 & & \\
\hline HFBe:FCl $(Z)$ & -96.3 & 785.8 & & \\
\hline $\mathrm{F}_{2} \mathrm{Be}: \mathrm{FCl}$ & -101.5 & 776.8 & & \\
\hline $\mathrm{Cl}_{2} \mathrm{Be}: \mathrm{FCl}$ & -96.5 & 767.9 & & \\
\hline $\mathrm{FCl}: \mathrm{NCH}$ & -57.5 & 753.0 & -32.3 & -32.7 \\
\hline $\mathrm{H}_{2} \mathrm{Be}: \mathrm{FCl}: \mathrm{NCH}$ & 54.3 & 662.5 & -57.2 & -58.0 \\
\hline HFBe:FCl:NCH( $E)$ & 49.3 & 654.5 & -58.3 & -59.1 \\
\hline HFBe:FCl:NCH $(Z)$ & 71.3 & 659.5 & -57.9 & -58.7 \\
\hline $\mathrm{F}_{2} \mathrm{Be}: \mathrm{FCl}: \mathrm{NCH}$ & 134.5 & 644.8 & -54.2 & -54.9 \\
\hline $\mathrm{Cl}_{2} \mathrm{Be}: \mathrm{FCl}: \mathrm{NCH}$ & 380.0 & & 18.0 & \\
\hline${ }^{+} \mathrm{Cl}-\mathrm{NCH}$ & & & 48.6 & 48.8 \\
\hline $\mathrm{FCl}: \mathrm{NH}_{3}$ & 36.9 & 693.6 & -48.2 & -51.1 \\
\hline $\mathrm{H}_{2} \mathrm{Be}: \mathrm{FCl}: \mathrm{NH}_{3}$ & 294.2 & 562.8 & -17.3 & -25.9 \\
\hline HFBe:FCl:NH ${ }_{3}(E)$ & 293.9 & 550.2 & -16.1 & -24.9 \\
\hline HFBe:FCl: $\mathrm{NH}_{3}(Z)$ & 299.3 & 550.5 & -14.7 & -23.7 \\
\hline $\mathrm{F}_{2} \mathrm{Be}: \mathrm{FCl}: \mathrm{NH}_{3}$ & 322.7 & 549.8 & -10.5 & -19.9 \\
\hline $\mathrm{Cl}_{2} \mathrm{Be}: \mathrm{FCl}: \mathrm{NH}_{3}$ & 326.2 & & 1.4 & \\
\hline${ }^{+} \mathrm{Cl}-\mathrm{NH}_{3}$ & & & 21.7 & 8.5 \\
\hline $\mathrm{FCl}: \mathrm{NHCH}_{2}$ & 60.0 & 679.6 & -54.0 & -55.4 \\
\hline $\mathrm{H}_{2} \mathrm{Be}: \mathrm{FCl}: \mathrm{NHCH}_{2}$ & 336.8 & 497.4 & 6.5 & 3.7 \\
\hline HFBe:FCl: $\mathrm{NHCH}_{2}(E)$ & 330.3 & 480.7 & 7.8 & 5.0 \\
\hline HFBe:FCl: $\mathrm{NHCH}_{2}(Z)$ & 329.2 & 473.1 & 9.6 & 6.8 \\
\hline $\mathrm{F}_{2} \mathrm{Be}: \mathrm{FCl}: \mathrm{NHCH}_{2}$ & 338.2 & & 12.6 & \\
\hline $\mathrm{Cl}_{2} \mathrm{Be}: \mathrm{FCl}: \mathrm{NHCH}_{2}$ & 300.7 & & 20.4 & \\
\hline${ }^{+} \mathrm{Cl}-\mathrm{NHCH}_{2}$ & & & 27.9 & 21.6 \\
\hline
\end{tabular}

$$
\mathrm{H}_{2} \mathrm{Be}>\mathrm{HFBe}>\mathrm{F}_{2} \mathrm{Be}
$$

although the values for HFBe:FCl: $\mathrm{NH}_{3}$ and $\mathrm{F}_{2} \mathrm{Be}: \mathrm{FCl}: \mathrm{NH}_{3}$ are essentially the same. For fixed acid, the order of decreasing ${ }^{1} J(\mathrm{~F}-\mathrm{Cl})$ with respect to the base is

$$
\mathrm{NHCH}_{2}>\mathrm{NH}_{3}>\mathrm{NCH} \text {. }
$$

The changes in ${ }^{1} J(\mathrm{~F}-\mathrm{Cl})$ upon formation of binary and ternary complexes are illustrated in Fig. 6.

${ }^{1 \mathbf{x}} J(\mathbf{C l}-\mathbf{N})$. Table 6 also provides the FC terms and total $J$ for the third coupling constant of interest, ${ }^{1 \mathrm{X}} J(\mathrm{Cl}-\mathrm{N})$. This coupling constant is large and negative in the binary complexes, and in the ternary complexes with $\mathrm{NCH}$ and $\mathrm{NH}_{3}$. It eventually decreases as the strength of the beryllium acid increases, changes sign, and is positive in the cations ${ }^{+} \mathrm{Cl}-\mathrm{NCH}$ and ${ }^{+} \mathrm{Cl}-$ $\mathrm{NH}_{3}$. All ternary complexes with $\mathrm{NHCH}_{2}$ as the base have positive values of ${ }^{1 \mathrm{X}} J(\mathrm{Cl}-\mathrm{N})$, with the largest value occurring in the cation ${ }^{+} \mathrm{Cl}-\mathrm{NHCH}_{2}$. For fixed acid, ${ }^{1 \mathrm{X}} \mathrm{J}(\mathrm{Cl}-\mathrm{N})$ in the ternary complexes increases in the order

$$
\mathrm{NCH}<\mathrm{NH}_{3}<\mathrm{NHCH}_{2}
$$

while ${ }^{1} J(\mathrm{Cl}-\mathrm{N})$ for the cations increases in the order

$$
{ }^{+} \mathrm{Cl}-\mathrm{NH}_{3}<{ }^{+} \mathrm{Cl}-\mathrm{NHCH}_{2}<{ }^{+} \mathrm{Cl}-\mathrm{NCH} \text {. }
$$

Fig. 7 provides a plot of ${ }^{1 \mathrm{X}} \mathrm{J}(\mathrm{Cl}-\mathrm{N})$ versus the $\mathrm{Cl}-\mathrm{N}$ distance. The points for each base at the longest distance are the values in the binary complex, while the point at the shortest distance corresponds to the cation. The ternary complexes with a given

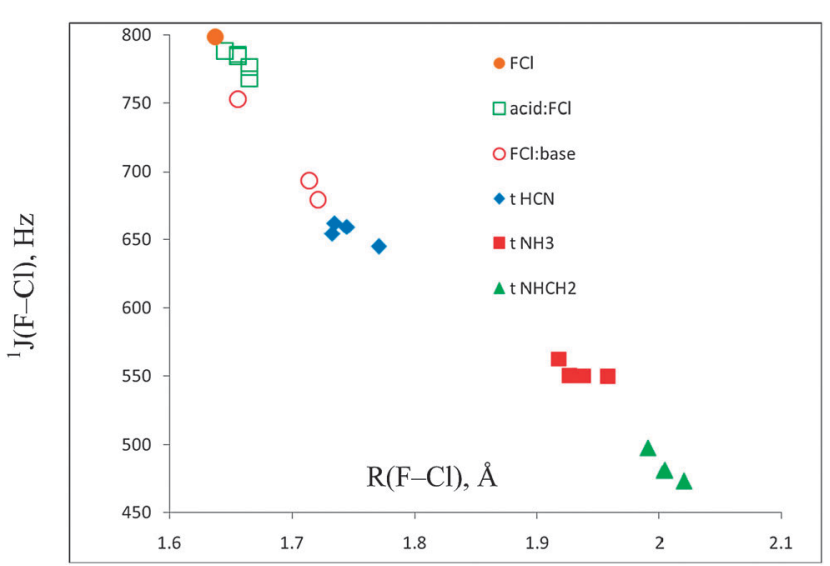

Fig. $6{ }^{1} \mathrm{~J}(\mathrm{~F}-\mathrm{Cl})$ versus the $\mathrm{F}-\mathrm{Cl}$ distance in $\mathrm{FCl}$, binary complexes $\mathrm{FCl}$ : $\mathrm{N}$-base and $\mathrm{XYBe}: \mathrm{FCl}$, and ternary complexes XYBe:FCl:N-base.

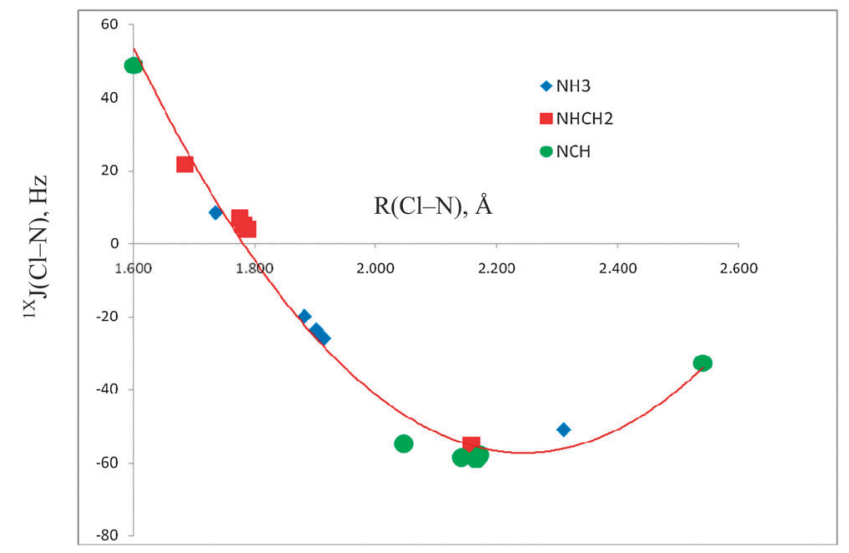

Fig. $7^{1 \times} \mathrm{J}(\mathrm{Cl}-\mathrm{N})$ versus the $\mathrm{Cl}-\mathrm{N}$ distance in binary complexes $\mathrm{FCl}$ : $\mathrm{N}$-base, ternary complexes $\mathrm{XYBe}: \mathrm{FCl}: \mathrm{N}$-base, and cations ${ }^{+} \mathrm{Cl}-\mathrm{N}$-base. The points for each base at the longest $\mathrm{Cl}-\mathrm{N}$ distance are for the binary complexes.

base are grouped together between these endpoints. The values of ${ }^{1 \mathrm{X}} J(\mathrm{Cl}-\mathrm{N})$ can be fitted by a second-order trendline, which has a correlation coefficient $R^{2}$ of 0.983 . Of course, it should be recognized that at longer $\mathrm{Cl}-\mathrm{N}$ distances, the curvature of the trendline will change as ${ }^{1 \mathrm{x}} J(\mathrm{Cl}-\mathrm{N})$ asymptotically approaches $0 \mathrm{~Hz}$. For comparison, the value of ${ }^{1 \mathrm{x}} J(\mathrm{Cl}-\mathrm{N})$ for the binary complex of FCl with the very weak base $\mathrm{N}_{2}$ is $-13.9 \mathrm{~Hz}$ at a Cl-N distance of $2.802 \AA$.

Just as the structures, binding energies, and bonding properties of the binary and ternary complexes illustrate an evolution of the halogen-bond type from traditional to chlorine-shared to ion-pair bonds, so do the coupling constants ${ }^{1 \mathrm{X}} J(\mathrm{Cl}-\mathrm{N})$, which are plotted against the $\mathrm{Cl}-\mathrm{N}$ distance in Fig. 7. The plot suggests that all of the complexes XYBe:FCl:NCH are stabilized by traditional halogen bonds, except for $\mathrm{Cl}_{2} \mathrm{Be}$ :FCl:NCH. Since the FC terms for the ternary complexes with $\mathrm{NCH}$ are excellent approximations to ${ }^{1 \mathrm{X}} \mathrm{J}(\mathrm{Cl}-\mathrm{N})$, its value of $18 \mathrm{~Hz}$ at a Cl-N distance of $1.742 \AA$ suggests that $\mathrm{Cl}_{2} \mathrm{Be}: \mathrm{FCl}: \mathrm{NCH}$ is stabilized by an ion-pair halogen bond. Fig. 7 suggests that chlorine-shared halogen bonds are found in all complexes XYBe:FCl: $\mathrm{NH}_{3}$ except for $\mathrm{Cl}_{2} \mathrm{Be}: \mathrm{FCl}: \mathrm{NH}_{3}$, which has 
an ion-pair bond. Finally, ${ }^{1 \mathrm{X}} J(\mathrm{Cl}-\mathrm{N})$ values indicate that all complexes XYBe:FCl: $\mathrm{NHCH}_{2}$ are stabilized by ion-pair halogen bonds.

\section{Conclusions}

Ab initio MP2/aug'-cc-pVTZ calculations have been carried out in this study to investigate the binary complexes $\mathrm{HFBe} F \mathrm{FCl}$, $\mathrm{R}_{2} \mathrm{Be}: \mathrm{FCl}$, and FCl:N-base, and the ternary complexes HFBe: FCl:N-base and $\mathrm{R}_{2} \mathrm{Be}: \mathrm{FCl}$ :N-base, for $\mathrm{R}=\mathrm{H}, \mathrm{F}, \mathrm{Cl}$; and $\mathrm{N}$-base $=$ $\mathrm{NH}_{3}, \mathrm{NHCH}_{2}, \mathrm{NCH}$. The presence of Be. $\mathrm{F}$ beryllium bonds and $\mathrm{Cl} \cdots \mathrm{N}$ halogen bonds leads to dramatic, synergistic cooperative effects on the structures, binding energies, and bonding characteristics of ternary complexes. Charge transfer from $\mathrm{F}$ to $\mathrm{Be}$ across the beryllium bond and from $\mathrm{N}$ to $\mathrm{Cl}$ across the halogen bond strengthens both $\mathrm{Be} \cdots \mathrm{F}$ and $\mathrm{Cl} \cdots \mathrm{N}$ bonds, and weakens the $\mathrm{F}-\mathrm{Cl}$ bond. Charge transfer to the empty $\mathrm{p}(\sigma)$ orbital of Be increases the electron density of Be and leads to a change in hybridization. In the limit, XYBe approaches $\mathrm{sp}^{2}$ hybridization, and in the more strongly bound complexes, the interaction is sufficient to generate an ion-pair, such as $\left[\mathrm{Cl}_{2} \mathrm{Be}: \mathrm{F}\right]^{-} \cdots\left[\mathrm{Cl}: \mathrm{NHCH}_{2}\right]^{+}$, as heterolytic cleavage of the $\mathrm{F}-\mathrm{Cl}$ bond occurs. The mechanism for cleavage is similar to that involved in the dissociative proton attachment process. As a function of the intrinsic basicity of the nitrogen base and the intrinsic acidity of the Be derivative, the halogen-bond type evolves smoothly from traditional to chlorine-shared to ion-pair bonds. EOM-CCSD spin-spin coupling constants ${ }^{1 \mathrm{X}} J(\mathrm{Cl}-\mathrm{N})$ across the halogen bond also provide evidence of the evolution of the halogen-bond type in these complexes.

\section{Acknowledgements}

This work has been partially supported by the Ministerio de Economía y Competitividad (Project No. CTQ2012-35513-C02), the Project Fotocarbon, ref. S2013/MIT-2841 of the Comunidad Autónoma de Madrid, by Consolider on Molecular Nanoscience CSC2007-00010, and by the CMST COST Action CM1204. A generous allocation of computing time at the CTI (CSIC) and at the CCC of the UAM, and the continuing support of the Ohio Supercomputer Center are also acknowledged.

\section{References}

1 P. Politzer, J. S. Murray and T. Clark, Phys. Chem. Chem. Phys., 2013, 15, 11178-11189.

2 P. Metrangolo and G. Resnati, Halogen Bonding: Fundamentals and Applications, Spinger, 2008.

3 L. P. Wolters, P. Schyman, M. J. Pavan, W. L. Jorgensen, F. M. Bickelhaupt and S. Kozuch, Wiley Interdiscip. Rev.: Comput. Mol. Sci., 2014, 4, 523-540.

4 J. E. Del Bene, I. Alkorta and J. Elguero, J. Phys. Chem. A, 2010, 114, 12958-12962.

5 J. E. Del Bene, I. Alkorta and J. Elguero, Phys. Chem. Chem. Phys., 2011, 13, 13951-13961.
6 J. E. Del Bene, I. Alkorta and J. Elguero, Chem. Phys. Lett., 2011, 508, 6-9.

7 L. J. McAllister, D. W. Bruce and P. B. Karadakov, J. Phys. Chem. A, 2011, 115, 11079-11086.

8 P. Politzer and J. S. Murray, Theor. Chem. Acc., 2012, 131, 1114.

9 I. Alkorta, G. Sánchez-Sánz, J. Elguero and J. E. Del Bene, J. Phys. Chem. A, 2012, 116, 2300-2308.

10 Q. Li, S. Ma, X. Liu, W. Li and J. Cheng, J. Chem. Phys., 2012, 137, 084314.

11 I. Alkorta, J. Elguero and J. E. Del Bene, J. Phys. Chem. A, 2014, 118, 4222-4231.

12 O. Donoso-Tauda, P. Jaque, J. Elguero and I. Alkorta, J. Phys. Chem. A, 2014, 118, 9552-9560.

13 Q. Li, X. Liu, R. Li, J. Cheng and W. Li, Spectrochim. Acta, Part A, 2012, 90, 135-140.

14 K. Eskandari, J. Mol. Model., 2012, 18, 3481-3487.

15 M. Yáñez, P. Sanz, O. Mó, I. Alkorta and J. Elguero, J. Chem. Theory Comput., 2009, 5, 2763-2771.

16 I. Alkorta, J. Elguero, M. Yáñez and O. Mó, Phys. Chem. Chem. Phys., 2014, 16, 4305-4312.

17 O. Mó, M. Yáñez, I. Alkorta and J. Elguero, J. Chem. Theory Comput., 2012, 8, 2293-2300.

18 L. Albrecht, R. J. Boyd, O. Mó and M. Yáñez, Phys. Chem. Chem. Phys., 2012, 14, 14540-14547.

19 L. Albrecht, R. J. Boyd, O. Mó and M. Yáñez, J. Phys. Chem. A, 2014, 118, 4205-4213.

20 J. E. Del Bene, I. Alkorta and J. Elguero, J. Phys. Chem. A, 2008, 112, 7925-7929.

21 J. A. Pople, J. S. Binkley and R. Seeger, Int. J. Quantum Chem., Quantum Chem. Symp., 1976, 10, 1-19.

22 R. Krishnan and J. A. Pople, Int. J. Quantum Chem., 1978, 14, 91-100.

23 R. J. Bartlett and D. M. Silver, J. Chem. Phys., 1975, 62, 3258-3268.

24 R. J. Bartlett and G. D. Purvis, Int. J. Quantum Chem., 1978, 14, 561-581.

25 J. E. Del Bene, J. Phys. Chem., 1993, 97, 107-110.

26 T. H. Dunning, J. Chem. Phys., 1989, 90, 1007-1023.

27 D. E. Woon and T. H. Dunning, J. Chem. Phys., 1995, 103, 4572-4585.

28 M. J. Frisch, G. W. Trucks, H. B. Schlegel, G. E. Scuseria, M. A. Robb, J. R. Cheeseman, G. Scalmani, V. Barone, B. Mennucci, G. A. Petersson, H. Nakatsuji, M. Caricato, X. Li, H. P. Hratchian, A. F. Izmaylov, J. Bloino, G. Zheng, J. L. Sonnenberg, M. Hada, M. Ehara, K. Toyota, R. Fukuda, J. Hasegawa, M. Ishida, T. Nakajima, Y. Honda, O. Kitao, H. Nakai, T. Vreven, J. A. Montgomery, J. E. Peralta, F. Ogliaro, M. Bearpark, J. J. Heyd, E. Brothers, K. N. Kudin, V. N. Staroverov, R. Kobayashi, J. Normand, K. Raghavachari, A. Rendell, J. C. Burant, S. S. Iyengar, J. Tomasi, M. Cossi, N. Rega, N. J. Millam, M. Klene, J. E. Knox, J. B. Cross, V. Bakken, C. Adamo, J. Jaramillo, R. Gomperts, R. E. Stratmann, O. Yazyev, A. J. Austin, R. Cammi, C. Pomelli, J. W. Ochterski, R. L. Martin, K. Morokuma, V. G. Zakrzewski, G. A. Voth, P. Salvador, 
J. J. Dannenberg, S. Dapprich, A. D. Daniels, Ö. Farkas, J. B. Foresman, J. V. Ortiz, J. Cioslowski and D. J. Fox, Gaussian, Inc., Wallingford CT, 2009.

29 D. Hankins, J. W. Moskowitz and F. H. Stillinger, J. Chem. Phys., 1970, 53, 4544-4554.

30 S. Xantheas, J. Chem. Phys., 1994, 100, 7523-7534.

31 R. F. W. Bader, Chem. Rev., 1991, 91, 893-928.

32 R. F. W. Bader, Atoms in Molecules, A Quantum Theory, Oxford University Press, Oxford, 1990.

33 P. L. A. Popelier, Atoms In Molecules. An introduction, Prentice Hall, Harlow, England, 2000.

34 C. F. Matta and R. J. Boyd, The Quantum Theory of Atoms in Molecules: From Solid State to DNA and Drug Design, WileyVCH, Weinham, 2007.

35 T. A. Keith, AIMAll (Version 11.08.23), TK Gristmill Software, Overland Park KS, USA, 2011 (aim.tkgristmill.com).

36 I. Rozas, I. Alkorta and J. Elguero, J. Am. Chem. Soc., 2000, 122, 11154-11161.

37 T. Lu and F. Chen, J. Comput. Chem., 2012, 33, 580-592.

38 A. E. Reed, L. A. Curtiss and F. Weinhold, Chem. Rev., 1988, 88, 899.

39 A. E. Reed, L. A. Curtiss and F. Weinhold, Chem. Rev., 1988, 88, 899-926.

40 A. D. Becke, J. Chem. Phys., 1993, 98, 5648-5652.

41 C. Lee, W. Yang and R. G. Parr, Phys. Rev. B: Condens. Matter Mater. Phys., 1988, 37, 785-789.

42 S. A. Perera, M. Nooijen and R. J. Bartlett, J. Chem. Phys., 1996, 104, 3290-3305.

43 S. A. Perera, H. Sekino and R. J. Bartlett, J. Chem. Phys., 1994, 101, 2186-2196.

44 A. Schäfer, H. Horn and R. Ahlrichs, J. Chem. Phys., 1992, 97, 2571-2577.

45 J. E. Del Bene, J. Elguero, I. Alkorta, M. Yañez and O. Mó, J. Phys. Chem. A, 2006, 110, 9959-9966.
46 ACES II is a program product of the Quantum Theory Project, University of Florida. Authors: J. F. Stanton, J. Gauss, J. D. Watts, M. Nooijen, N. Oliphant, S. A. Perera, P. G. Szalay, W. J. Lauderdale, S. R. Gwaltney, S. Beck, A. Balkova, E. D. Bernholdt, K.-K. Baeck, P. Tozyczko, H. Sekino, C. Huber and R. J. Bartlett, Integral packages included are VMOL (J. Almlof and P. R. Taylor), VPROPS (P. R. Taylor), ABACUS (T. Helgaker, H. J. A. Jensen, P. Jorgensen, J. Olsen and P. R. Taylor). Brillouin-Wigner perturbation theory was implement by J. Pittner.

47 I. Alkorta, F. Blanco, P. M. Deyà, J. Elguero, C. Estarellas, A. Frontera and D. Quiñonero, Theor. Chem. Acc., 2009, 126, 1-14.

48 P. Politzer, K. E. Riley, F. A. Bulat and J. S. Murray, Comput. Theor. Chem., 2012, 998, 2-8.

49 O. Knop, R. J. Boyd and S. C. Choi, J. Am. Chem. Soc., 1988, 110, 7299-7301.

50 G. V. Gibbs, F. C. Hill, M. B. Boisen and R. T. Downs, Phys. Chem. Miner., 1998, 25, 585-590.

51 I. Alkorta, L. Barrios, I. Rozas and J. Elguero, THEOCHEM, 2000, 496, 131-137.

52 O. Knop, K. N. Rnakin and R. J. Boyd, J. Phys. Chem. A, 2001, 105, 6552-6566.

53 O. Knop, K. N. Rnakin and R. J. Boyd, J. Phys. Chem. A, 2003, 107, 272-284.

54 E. Espinosa, I. Alkorta, J. Elguero and E. Molins, J. Chem. Phys., 2002, 117, 5529-5542.

55 I. Alkorta and J. Elguero, Struct. Chem., 2004, 15, 117-120.

56 T. H. Tang, E. Deretey, S. J. Knak Jensen and I. G. Csizmadia, Eur. Phys. J. D, 2006, 37, 217-222.

57 I. Mata, I. Alkorta, E. Molins and E. Espinosa, Chem. - Eur. J., 2010, 16, 2442-2452.

58 J. L. M. Abboud, R. Notario, E. Ballesteros, M. Herreros, O. Mó, M. Yáñez, J. Elguero and G. Boyer, J. Am. Chem. Soc., 1994, 116, 2486-2492. 